\title{
Sexual Lifestyle and Socio-demographic Profile of Female Floating Sex Workers in some Selected Areas of Dhaka city
}

\author{
Mahejabin $\mathrm{F}^{1}$, Nahar $\mathrm{L}^{2}$, Parveen $\mathrm{S}^{3}$
}

\begin{abstract}
A descriptive cross-sectional study was conducted for a period of six months in some locations of Dhaka city. Data was collected from 90 floating sex workers to find out their socio-demographic characteristics, sexual lifestyle particularly safe sex by using condom among them. Of the 90 respondents, mean age of the respondents was $22.21(+4.87)$ with a range of $<18$ to $>26$ years. 42 $(46.7 \%)$ of the respondents were married. $73(81.1 \%)$ of the respondents were the main earning member of the family. The mean family income was Taka 7700 (+3872.838). Majority 33(36.7\%) of the respondents were illiterate. The main reason for accepting sex selling profession it was found that more than half i.e. $62(68.9 \%)$ of the respondents were bluffed and $24(26.7 \%)$ respondents accepted this profession of their own will. The duration of sex work of $29(32.2 \%)$ of the respondents was less than 1 year (6-8 months) and 24 (26.6\%) of the respondents were 4-5 years. 59 of the respondent always used condoms (65.6\%). A significant number of respondents, $31(34.4 \%)$ did not use condom. The reason for not using condom was client's dissatisfaction $(25,80.6 \%)$ and 4 $(12.9 \%)$ respondents used other methods of contraception. Among the respondents, $78(86.7 \%)$ used condom during last sexual intercourse. In the study, 45 (76.3\%) respondents knew condom as a preventive measure and advocated its use in each sexual intercourse. $\left(\mathrm{X}^{2}=4.356 ; \mathrm{d} f=1 \mathrm{P}=0.037\right)$. $60(76.3 \%)$ of the respondents knew condom use as a preventive measure and used it in last sexual intercourse and highly significant association was found $\left(\mathrm{X}^{2}=17.61 ; \mathrm{df}=1 \mathrm{P}<0.001\right)$ between knowledge and practice. Promoting constant condom usage with clients among the female floating sex workers should be sustained and reinforced.
\end{abstract}

\section{Key Words}

Female floating sex worker, Condom use, Sexual life style.

\section{Introduction}

Migrant workers have been identified as a population at risk for acquiring and transmitting HIV in many countries. ${ }^{1,2,3}$ For several reasons female migrants are believed to be more vulnerable than their male counterparts. First, women have greater biological susceptibility to HIV during sexual intercourse. The risk of HIV infection through unprotected vaginal sex with an infected person is estimated to be 2 to 4 times higher for women than for men. ${ }^{4}$ Second, inequality in power and socioeconomic status places women at greater risk of HIV infection. In many developing countries, women are dependent on men socially, economically, and / or emotionally, thus impairing their ability to persuade their sexual partners to use condoms. ${ }^{5}$ Third, the 


\section{ORIGINAL ARTICLE}

social context of the work setting may also put female migrant workers at increased risk of exposure to various risk behaviours. Most male migrants work in labour-intensive industries, while most female migrants work in entertainment or service industries. ${ }^{6}$

There are 105,000 sex workers in Bangladesh; of whom about 100,000 are female sex workers. Most female sex workers are adolescents or young women, with the majority aged between 15 to 18 . The two major categories of female sex workers in Bangladesh are those who work in brothels, and floating sex workers. Floating sex workers are either hotel-based or street-based. Brothel-based female sex workers see approximately 18 clients per week, while street-based and hotel-based sex workers see an average of 17 and 44 clients per week respectively (World Bank, 2009). ${ }^{7}$

Female sex workers are at high risk for infection with HIV/AIDS, and their clients may act as a bridge population by spreading HIV to the general population. ${ }^{8}$ Condom use among clients of female sex workers in Bangladesh is variable. According to sixth round Behavioral Surveillance Survey (BSS, 2006-2007) data, condom use was $70 \%$ for clients of brothels and ranged between $51 \%$ and $81 \%$ for clients of street workers. Condom use was lowest among hotel-based sex workers in Dhaka and Chittagong at $40 \%$ and $36 \%$ respectively. Hotel-based sex workers are particularly vulnerable to HIV as they have the largest number of clients. The higher rate of condom use in brothels reflects the fact that licensed brothels is legal, making it easier for health officials to distribute condoms (BBC, 2000). Consistent condom use with regular clients is lower for sex workers in brothels, hotels and on the street. STD rates are relatively high among sex workers in all categories, but particularly among hotel and street-based workers, indicating the presence of risky sexual practices facilitating the spread of HIV (World Bank, 2009). ${ }^{9}$ Mobile Sex Workers (M-SWs) are closely associated with the tourism and transport industries where they find a large supply of potential clients. Tourism, which provides additional clients for sex workers, and transport workers, who exploit commercial sex workers, facilitates transmission of the virus to the general population. ${ }^{10}$ Knowledge about the HIV/STDs epidemic status is urgently needed to develop an appropriate prevention and control program, as well as to provide valuable evidence for allocating resources for AIDS treatment and behavioral interventions among floating sex worker. ${ }^{11}$

In Bangladesh, small or insignificant amount of information about sex sales is found from government or non-government organizations. As there is strong religious beliefs and backward social tradition, sex related matters are not discussed freely or publicly in the communities. In addition, research on sex-selling profession has little attention in Bangladesh. However, it is essential to address sexual lifestyle and socioeconomic profile of the sex sellers scientifically as early as possible. Therefore, the aim of this work and in continuation of research in this field was to investigate sexual lifestyle and socio-economic 
profile of the floating female sex-workers in Bangladesh.

\section{Materials and Methods}

The descriptive cross-sectional study was conducted for a period of six months from January to June 2011 in some locations of Dhaka city. Data was collected from 90 female floating sex workers to find their sexual lifestyle and socio-demographic characteristics. A total of 90 female floating sex workers were interviewed. Among them, 35 (38.9\%) were from Kamlapur, 23 (25.6\%) from Gulistan, 14 (15.5\%) from Moghbazar and 6 (6.7\%) from Fokirerpul areas of Dhaka city. The required sample size of the cross-sectional study was calculated by using the statistical formula: $\mathrm{n}=\mathrm{Z}^{2} \mathrm{pq} / \mathrm{d}^{2}$. The required sample size determined was 171; due to inconvenience of time and resources, the sample size was limited to 90 respondents. Purposive sampling technique was followed to minimize time constrain. An interview schedule with semi-structured questionnaire was used for data collection. The questionnaire were primarily written in English then translated to Bangla. They were interviewed after fulfilling the informed consent form. Confidentiality was guaranteed to every respondent to increase the accuracy and honesty of the response. Any information gathered through discussions or any other means remained confidential during the research period and after the research had been completed. Only the researcher had access to the information and participant's names were not available to anyone and are not present in the study. All notes taken will be destroyed at the completion of the study. The respondents in this study were completely voluntary and refusal to participate involved no penalty. Each respondent was free to withdraw consent and discontinue in this research at any time without consequence. The instrument was pre-tested on fifteen respondents in places other than the study area. All the data was checked and edited after collection. Then data was analyzed in the computer using SPSS for Windows' XP program version 12.0.

There are some limitations in the study. First, interviews were carried out in private and with guarantees of anonymity and confidentiality. Second, respondents felt uneasy to some of the questions about sexual lifestyle. Third, the sample size is small. Despite these limitations, the findings of the study provide some insight into the potential for female floating sex workers to be conduits for HIV transmission into the general population.

\section{Result}

Out of the 90 respondents, mean age of the respondents was $22.21 \mathrm{SD} \pm 4.87$ years with a range of $\leq 18$ to $\geq 26$ years. Among the respondents, majority $42(46.7 \%)$ of the respondents were married, 19 (21.1\%) respondents were unmarried, $12(13.3 \%)$ were divorced and 15 (16.7\%) were separated from their husband respectively. 88 (97.8\%) of the respondents were Muslims and only $2(2.2 \%)$ were Hindus. Regarding educational level, 33 $(36.7 \%)$ of the respondents were illiterate, 26 $(28.9 \%)$ could sign only, 18 (20.0\%) respondents were educated up to primary and 


\section{ORIGINAL ARTICLE}

$13(14.4 \%)$ respondents educated up to secondary level respectively. $73(81.1 \%)$ of the respondents were the main earning member of the family. The mean family income was Taka 7700.00 ( $\mathrm{SD} \pm 3872.838$ ). The majority, 52 $(57.7 \%)$ of the respondents had monthly income in between Taka 5001-10,000 followed by $30(33.3 \%)$ respondents who had income of Tk. $<5000$ and $8(8.8 \%)$ respondents had income of Tk. $>10000$ respectively. (Table: 1 ) The main reason for accepting sex selling profession we found out was, majority 62 $(68.9 \%)$ of the respondents were bluffed and 24 (26.7\%) respondents accepted this profession by own will. The duration of sex work of 29 $(32.2 \%)$ of the respondents was less than 1 year (6-8 months) and 24 (26.6\%) respondents were 4-5 years. Majority, $57(63.3 \%)$ of the respondents entertained 3-5 clients per day and $30 \quad(33.3 \%)$ respondents entertained 6-10 clients per day. $36(40 \%)$ of the clients were rickshaw puller and $20(22.2 \%)$ were truck drivers. To prevent unwanted pregnancy, majority $59(65.6 \%)$ of them used condom by their clients and 31 (34.4\%) respondents did not use condom by their clients. The reason of not using condom, was the clients did not like to use it $(25,80.6 \%)$ and $4(12.9 \%)$ respondents used other methods of contraception. For safe sex to prevent sexually transmitted infections (STIs), majority of the sex workers tried their level best to use condom by their clients in each sex but some others did not use it regularly. Among the respondents, 78 (86.7\%) used condom in last sexual intercourse and 12 (13.3\%) did not use condom during sex. (Table: 2) In the study, 45 (76.3\%) respondents knew condom as a preventive measure and advocated its use in each sexual intercourse. About 17 $(54.8 \%)$ respondents knew about condom but did not advocate its use in each intercourse. Chi-square test was done and significant association was found $\left(\mathrm{X}^{2}=4.356 ; \mathrm{d} \mathrm{f}=1 \mathrm{P}=\right.$ 0.037). (Table: 3) $60 \quad(76.3 \%)$ of the respondents knew condom use as a preventive measure and used it in last sexual intercourse. About 2 (16.7\%) respondents knew but did not use condom in last intercourse. Chi-square test was done and highly significant association was found $\left(\mathrm{X}^{2}=17.61 ; \mathrm{df}=1 \mathrm{P}<0.001\right)$ between knowledge and practice. (Table: 4 ) 
Table: 1 Distribution of socio-demographic characteristics of the re spondents $(n=90)$

\begin{tabular}{|c|c|c|c|}
\hline Age in group & Frequency & Percent & \\
\hline$\leq 18$ yrs & 23 & 25.6 & \\
\hline $19-20$ yrs & 17 & 18.9 & \\
\hline $21-22$ yrs & 16 & 17.8 & $\begin{array}{c}\text { Mean } \pm \text { SD }= \\
22.21 \pm 4.87\end{array}$ \\
\hline $23-25$ yrs & 20 & 22.2 & \\
\hline$\geq 26$ yrs & 14 & 15.6 & \\
\hline Religion & Frequency & Percent & \\
\hline Islam & 88 & 97.8 & \\
\hline Hindu & 2 & 2.2 & \\
\hline Marital status & Frequency & Percent & \\
\hline Married & 42 & 46.6 & \\
\hline Unmarried & 19 & 21.1 & \\
\hline Divorced & 12 & 13.3 & \\
\hline $\begin{array}{l}\text { Separated from } \\
\text { husband }\end{array}$ & 15 & 16.6 & \\
\hline Widow & 2 & 2.2 & \\
\hline Total & 90 & 100.0 & \\
\hline Level of education & Frequency & Percent & \\
\hline Illiterate & 33 & 36.7 & \\
\hline Primary & 25 & 27.8 & \\
\hline Secondary & 6 & 6.6 & \\
\hline Can sign only & 26 & 28.9 & \\
\hline $\begin{array}{l}\text { Main earning } \\
\text { member of family }\end{array}$ & Frequency & Percent & \\
\hline Self & 73 & 81.1 & \\
\hline Husband & 17 & 18.9 & \\
\hline Total & 90 & & \\
\hline $\begin{array}{l}\text { Monthly family } \\
\text { income }\end{array}$ & Frequency & Percent & \\
\hline Taka $<5000$ & 30 & 33.3 & \\
\hline Taka 5001-6000 & 10 & 57.7 & \\
\hline Taka 6001-8000 & 19 & & $\begin{array}{c}7700.00 \\
(\mathrm{SD} \pm \mathbf{3 8 7 2 . 8 3 8})\end{array}$ \\
\hline Taka 8001-10000 & 23 & & \\
\hline Taka $>10000$ & 8 & 8.8 & \\
\hline
\end{tabular}




\section{ORIGINAL ARTICLE}

Table 2: Sexual lifestyle and family profile of Female floating sex workers $(n=90)$

\begin{tabular}{|c|c|c|}
\hline $\begin{array}{l}\text { Cause of accepting this } \\
\text { profession }\end{array}$ & Frequency & Percent \\
\hline By own will & 24 & 26.7 \\
\hline Bluffed & 62 & 68.9 \\
\hline Poverty & 4 & 4.4 \\
\hline Total & 90 & 100.0 \\
\hline Length of employment & Frequency & $\%$ \\
\hline$<1$ year & 29 & 32.2 \\
\hline 2-3 years & 19 & 21.1 \\
\hline $4-5$ years & 24 & 26.6 \\
\hline$>6$ years & 18 & 20.0 \\
\hline Total & 90 & 100.0 \\
\hline Clients per day & Frequency & $\%$ \\
\hline $3-5$ & 57 & 63.3 \\
\hline $6-10$ & 30 & 33.3 \\
\hline $11-15$ & 03 & 3.3 \\
\hline Total & 90 & 100.0 \\
\hline Client's occupation & Frequency & percent \\
\hline Rickshaw pullers & 36 & 40.0 \\
\hline Truck driver & 20 & 22.2 \\
\hline Police & 14 & 15.5 \\
\hline Students & 12 & 13.3 \\
\hline Service holder & 08 & 08.9 \\
\hline Total & 90 & 100.0 \\
\hline $\begin{array}{l}\text { Condom use in each } \\
\text { intercourse }\end{array}$ & Frequency & $\%$ \\
\hline Yes & 59 & 65.5 \\
\hline No & 31 & 34.4 \\
\hline $\begin{array}{l}\text { Reasons for not advocating } \\
\text { condom }\end{array}$ & Frequency & $\%$ \\
\hline Clients do not like & 25 & 80.6 \\
\hline $\begin{array}{l}\text { Use other method of } \\
\text { contraception }\end{array}$ & 4 & 12.9 \\
\hline Others (abstinence) & 2 & 6.5 \\
\hline Total & 31 & 100 \\
\hline $\begin{array}{l}\text { Condom use in last sexual } \\
\text { intercourse }\end{array}$ & Frequency & $\%$ \\
\hline Yes & 78 & 86.7 \\
\hline No & 12 & 13.3 \\
\hline Total & 90 & 100 \\
\hline
\end{tabular}


Table: 3 Condom use as a way of prevention and advocating use of condom in each sexual intercourse

\begin{tabular}{|l|c|c|c|c|}
\hline \multirow{2}{*}{ Condom use as way of prevention } & \multicolumn{3}{|c|}{ Condom used in last sexual intercourse } \\
\cline { 2 - 5 } & \multicolumn{3}{|c|}{ Yes } & \multicolumn{2}{c|}{ No } \\
\cline { 2 - 5 } & $\mathrm{N}$ & $\%$ & $\mathrm{~N}$ & $\%$ \\
\hline Condom use & 45 & 76.3 & 17 & 54.8 \\
\hline Other measures & 14 & 23.7 & 14 & 45.2 \\
\hline Total & 59 & 100.0 & 31 & 100.0 \\
\hline
\end{tabular}

Table: 4 Condom use as a way of prevention and use of condom in last sexual intercourse

\begin{tabular}{|l|c|c|c|c|}
\hline \multirow{2}{*}{ Condom use as way of prevention } & \multicolumn{3}{|c|}{ Condom used in last sexual intercourse } \\
\cline { 2 - 5 } & \multicolumn{2}{|c|}{ Yes } & \multicolumn{2}{c|}{ No } \\
\cline { 2 - 5 } & $\mathrm{N}$ & $\%$ & $\mathrm{~N}$ & $\%$ \\
\hline Condom use & 60 & 76.9 & 2 & 16.7 \\
\hline Other measures & 18 & 23.1 & 10 & 83.3 \\
\hline Total & 78 & 100.0 & 12 & 100.0 \\
\hline
\end{tabular}

\section{Discussion}

In Bangladesh, sex selling is valued as a deserted profession by the most of the population. There is a strong religious as well as backward social traditional impact in the community against sex selling profession. In fact, internal migration and overseas migration and tourism create increased demand for prostitution which results in enhancing sex selling profession in Bangladesh. Sex work is widespread in Dhaka, particularly among people belonging to the lower social class. Dhaka has 14 acknowledged brothels and approximately 5,000-15,000 female sex workers (FSWs). ${ }^{12}$ So we conducted our research among female floating sex workers to assess their sexual lifestyle and socio-demographic profile.

The present study showed that majority 23 (25.6\%) of the respondents were at or below 18 years and the mean age was $22.2(\mathrm{SD} \pm 4.87)$ 
years. This finding was similar with the findings of the study done by Sereenen $\mathrm{E}^{13}$, Hesketh $\mathrm{T}^{14}$, Cai $Y^{15} .88(97.8 \%)$ of the respondents were Muslims and this finding was similar with our national finding. ${ }^{16}$ Majority, 30 (33.3\%) of the respondent's monthly income were Taka five thousand and among the respondents 59\% respondents were illiterate. These findings were not comparable with our national findings. ${ }^{16}$ In the study the duration of sex work was carried out for a short period of time. Majority, 57 $(63.3 \%)$ of the respondents entertained 3-5 clients per day and $30(33.3 \%)$ respondents entertained 6-10 clients per day. Several data showed that, FSWs usually have 3-5 clients per day. Brothel-based female sex workers have an average of 18 clients per week, street based female sex workers have an average of 17 clients per week, while hotel-based sex workers have an average of 44 clients per week. 17,18 Regular condom users were $65.6 \%$ which was similar with the findings of study done in Shanghai China. ${ }^{1}$ It was also observed in the study conducted by Simon Sentumbwe that $57.1 \%$ used condom during sex and $11.9 \%$ sex workers continued with unprotected sex. ${ }^{19}$ In the study $34.4 \%$ did not use condom because of client's dissatisfaction $(80.6 \%)$. The study done by Mondal et al showed that the low rate of condom use is a combined result of clients' dislike of condoms; lack of knowledge about their effectiveness, low risk perceptions, and poor situation and availability of condoms. ${ }^{20}$ Condom used in last sexual intercourse was $86.7 \%$ which was quite high. This is similar to the study done in Mongolia city by Enkhbold
S. ${ }^{13}$ In the BSS 2003-2004, condom use among different categories of FSWs with their most recent clients was $24.10 \%$ among the street-based floating sex workers. It was observed in the study that, there was highly significant association between knowledge and condom use during sex. Similar finding were found in the study done by Kapiga $\mathrm{SH}$ in Dar-es-salaam, Tanzania where the researcher observed that condom use was positively associated with increasing level of education. ${ }^{21}$

\section{Conclusion}

We conducted the study on a small sample of female floating sex workers in some locations of Dhaka city to identify the risky sexual behaviours practiced. There is a need to expand advocacy and awareness among sex workers to promote the social acceptability of condom use and ensure their adequate supply and access. Promoting constant condom usage with clients among the female floating sex workers should be sustained and reinforced. Effective preventive programs should be conducted not only among female floating sex workers but also among their clients.

\section{References}

1. Hope KR. Mobile workers and HIV/AIDS in Botswana. AIDS Analysis Africa. 2000;10: 6-7.

2. Lurie MN, Williams BG, Zuma K, Mkaya-Mwamburi D, Garnett G, Sturm AW et al. The impact of migration on HIV-1 transmission in South Africa: a study of migrant and non migrant men and their partners. Sexually Transmitted Diseases. 2003;30:149-56.

3. Li X, Fang X, Lin D, Mao R, Wang J, Cottrell L et al. HIV/STD risk behaviours and perceptions among rural-to-urban migrants in China. AIDS Education and Prevention. 2004; 16:538-56.

4. Turmen T. Gender and HIV/AIDS. International 
Journal of Gynecology \& Obstetrics. 2003;82:411-/18. 5. Tang CS, Wong C, \& Lee A M. Gender-related psychosocial and cultural factors associated with condom use among Chinese married women. AIDS Education and Prevention. 2001;13:329-42.

6. Feng W, Zuo X, \& Ruan D. Rural migrants in Shanghai: living under the shadow of socialism. The International Migration Review. 2002;36:520-45.

7. Islam A, Smyth R. The economic returns to good looks and risky sex in the Bangladesh commercial sex market. Department of Economics Monash University. August;2010.

8. Ghys PD, Jenkins C, Pisani E. HIV surveillance among female sex workers. AIDS 2001; 15(3): S33-S40.

9. New Era/Sacts/Family Health International. HIV/STD Prevalence and Risk Factors Among Migrant and Non-migrant Males of Acham District in Far-Western Nepal. Khatmandu, Nepal: Report to Family Health International. STD/AIDS Counseling and Training Service. 2002.

10. Alam MK, AIDS: Mobile sex workers Vulnerability RAIN BOW FOUNDATION. Published June 22. 2009. 11. Pan X, Zhu Y, Wang Q, Zheng H, Chen X et al. Prevalence of HIV, Syphilis, HCV and their high risk behaviors among migrant workers in Eastern China. PLoS ONE. 2013;8(2): e57258.

12. USAID, USAID Works to Prevent HIV/AIDS. Epidemic in Bangladesh at Http://www.usaid.gov/bd/stories/story_129.html 13. Enkhbold S, Tugsdelger S, Morita S Sakamoto J, Hamajima N. HIV/AIDS related knowledge and risk behaviors among female sex workers in two major cities of Mongolia. Nagoya J. Med. Sci. 2007;69:157-65.
14. Hesketh T, Zhang J, Qiang DJ. HIV knowledge and risk behavior of female sex workers in Yunnan Province, China: Potential as bridging groups to the general population. AIDS Care. November. 2005;17(8):958-66.

15. Cai Y, Shi R, Shen T, Pei B, Jiang X, Ye X et al. A study of HIV/AIDS related knowledge, attitude and behaviors among female sex workers in Shaghai China. BMC Public Health. 2010;10:377-83.

16. Statistical Pocket Book of Bangladesh 2007. Bangladesh Bureau of Statistics. Planning division, Ministry of Planning, Government of the people's republic of Bangladesh.

17. World Bank, HIV/AIDS in Bangladesh, August 2007. Available at http://siteresources.worldbank.org /INTSAREGTOPHIVAIDS/Resources/HIV-AIDS-brief-A ug07-BD.pdf

18. SAARC Tuberculosis \& HIV/AIDS Centre (STC), HIV/AIDS in the SAARC Region, Update 2006 at http://www.saarctb.com.np/downloads/HIV_AIDS_Upda te_2006.pdf

19. Sentumbwe S. Knowledge and sexual behavioural patterns related to HIV/AIDS among commercial sex workers in Kampala slum area. Gender Issues Research Report Series- No.15. Organization for Social Science Research in Eastern and Southern Africa.

20. Mondal MNI, Takaku H, Ohkusa Y, Sugawara T, Okabe N. HIV/AIDS Acquisition and Transmission in Bangladesh: Turning to the Concentrated Epidemic. Jpn. J. Infect.Dis. 2009;62:111-19.

21. Kapiga SH, L Wihula GK, Shao JF et al. Predictors of AIDS knowledge, condom use and high risk sexual behavior among women in Dar-es-salaam, Tanzania. Int J STD AIDS. 1995; May-June 6(3):175-83. 